\title{
Desain dan Analisis Sistem Tenaga dan Transmisi pada Mobil Bertenaga Listrik Ezzy ITS II
}

\author{
Nyoman Budi Kusuma Yoga dan I Nyoman Sutantra \\ Departemen Teknik Mesin, Fakultas Teknologi Industri, Institut Teknologi Sepuluh Nopember (ITS) \\ e-mail: tantra@me.its.ac.id
}

\begin{abstract}
Abstrak-Efek samping dari melonjaknya kapasitas kendaraan bermotor meliputi beberapa hal di antaranya adalah polusi dan kebutuhan akan bahan bakar. Melihat kondisi dimana jumlah bahan bakar yang ada sudah menipis dan pengaruh emisi dari kendaraan bermotor yang mencemari lingkungan serta kesehatan, sehingga kendaraan berbasis listrik dapat menjadi solusi. Mobil listrik dirasa akan lebih efektif, karena memiliki efisiensi lebih tinggi dibanding dengan kendaraan berbahan bakar minyak. Namun, permasalahan dari kendaraan bertenaga listrik adalah menentukan driveability dan torsi motor yang dapat dicapai agar menghasilkan tenaga yang setara dengan kendaraan berbahan bakar minyak pada berbagai medan jalan serta jarak tempuh yang lebih panjang. Pada penelitian ini terdapat 2 tahapan, yaitu tahap perhitungan dan tahap analisa terhadap sistem tenaga dan transmisi dari Mobil Listrik Ezzy II ITS. Pada tahap perhitungan adalah menghitung besar dari gaya hambat yang terjadi pada kendaraan, selanjutnya mencari spesifikasi dari motor dan baterai yang digunakan kendaraan dan yang terakhir adalah menghitung traksi dan power dari transmisi yang digunakan. Pada tahap analisa akan dilakukan analisa terhadap karakteristik traksi serta karakteristik power yang terjadi dari transmisi tersebut. Dari penelitian ini diperoleh spesifikasi motor yang sesuai adalah YASA Motor P400 series $30 \mathrm{kw}$ dan baterai LiFePO4 120Ah. Mobil Listrik Ezzy ITS II menggunakan 2 tingkat transmisi dengan rasio tingkat pertama $\mathbf{2 . 3 6 2}$ dan tingkat kedua 0,36. Dari rasio transmisi tersebut karakteristik yang dihasilkan adalah dengan transmisi pertama kendaraan dapat melaju sampai $12 \mathrm{~km} /$ jam pada sudut tanjakan 30 derajat, serta kecepatan maksimum dari transmisi pertama adalah 93,09 km/jam pada jalan mendatar. Sedangkan untuk transmisi kedua dapat digunakan pada jalan mendatar dengan kecepatan mencapai $127 \mathrm{~km} /$ jam. Mobil Listrik Ezzy II ITS dengan daya motor $30 \mathrm{Kw}$ dapat dipilih karena sudah mampu memenuhi parameter rancangan yaitu dapat melewati tanjakan 30 derajat dengan kecepatan $10 \mathrm{~km} / \mathrm{jam}$ dan pada jalan datar dengan kecepatan 100 km/jam.
\end{abstract}

Kata Kunci-Motor Listrik, Gaya Hambat, Transmisi, Traksi.

\section{PENDAHULUAN}

$\mathrm{E}$ FEK samping dari melonjaknya kapasitas kendaraan bermotor meliputi beberapa hal di antaranya adalah polusi dan kebutuhan akan bahan bakar. Data dari BPH MIGAS menunjukkan konsumsi bahan bakar nasional pada tahun 2015 - 2017 terus mengalami peningkatan seiring dengan meningkatnya jumlah kendaraan bermotor, yaitu sebanyak 44.453.906 kiloliter di tahun 2015 dan 55.400.604 kiloliter di tahun 2017 [1]. Peneliti di Kitami Institute of Technology, Hokkaido, Jepang Marwan Rosyadi mengatakan energi fosil, seperti batu bara, minyak bumi, dan gas alam akan habis pada 2050 mendatang [2].

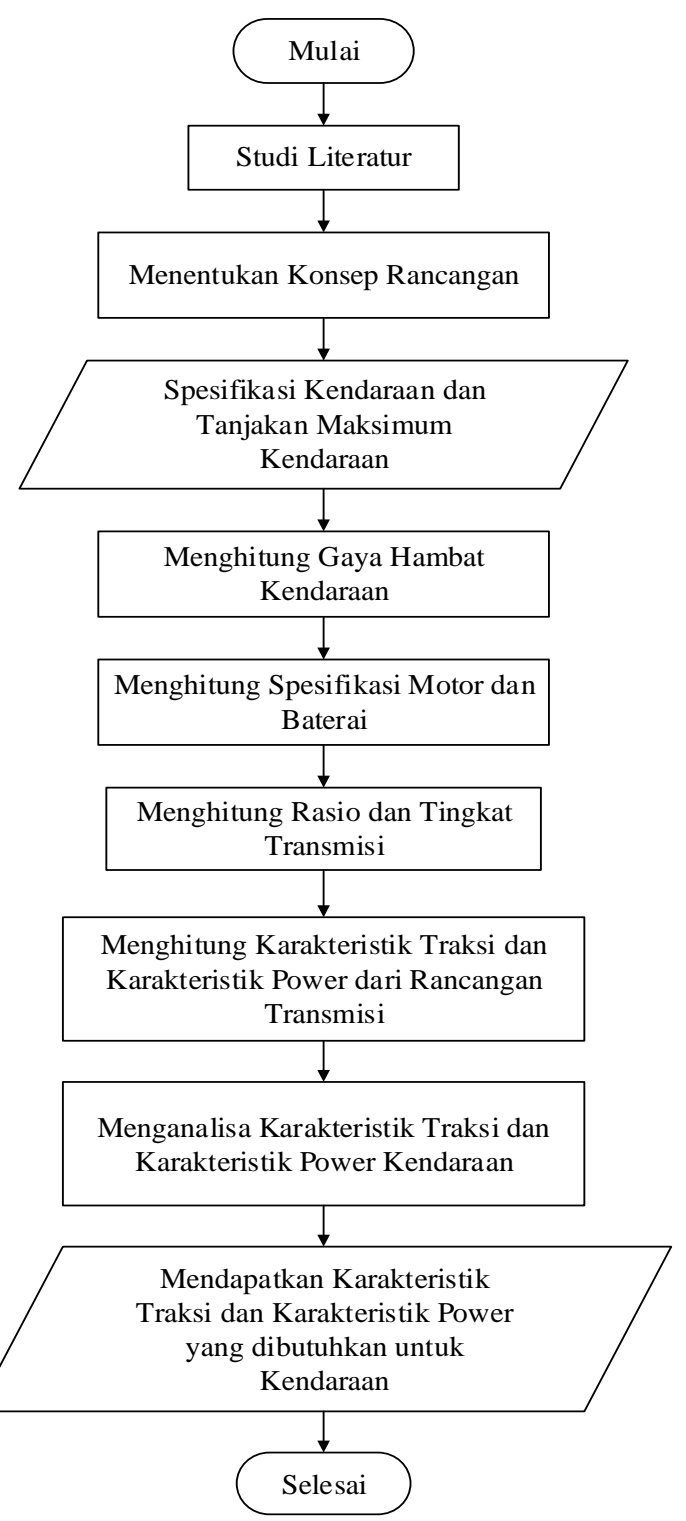

Gambar 1. Metode penelitian.

Bertambahnya kendaraan bermotor juga membawa dampak bagi kesehatan manusia. Hal ini disebabkan oleh gas buang yang ditimbulkan kendaraan bermotor tersebut. Polusi udara yang ditimbulkan oleh kendaraan bermotor sebesar 70-80\%. Gas karbon monoksida (CO) dan gas hidro karbon (HC) adalah polutan yang sangat berbahaya dari kendaraan bermotor tentunya akan mengganggu kesehatan manusia [3].

Menurut Kepala Balitbang Kementerian ESDM, FX Sutijastoto penggunaan mobil listrik dirasa akan lebih efektif, 
karena selain tidak menimbulkan polusi, suaranya halus, tahan lama, serta memiliki efisiensi energi yang tinggi dibanding dengan kendaraan berbahan bakar minyak [4]. Sebuah mobil listrik tentu membutuhkan beberapa komponen pendukung, yang salah satunya adalah motor listrik. Dalam hal ini motor listrik adalah sebagai komponen utama, yang berfungsi sebagai penggerak pada mobil listrik. Daya yang dibutuhkan kendaraan ini dihasilkan oleh motor listrik, kemudian daya tersebut disalurkan melalui sistem transmisi yang berfungsi untuk menyalurkan tenaga dari sumber penggerak sampai kebagian roda.

Namun permasalahan dari Mobil Listrik Ezzy II ITS daya motor listrik yang digunakan jauh lebih besar dibandingkan mobil listrik yang ada di pasaran. Dengan daya yang besar tentu jarak atau durasi tempuh yang dapat dicapai untuk sekali pengisian akan lebih singkat.

Pada tulisan ini mendapatkan hasil perhitungan untuk menentukan jenis motor dengan daya yang sesuai, lalu menganalisa transmisi, karakteristik traksi dari kendaraan, dan karakteristik power pada masing-masing tingkat transmisi. Analisa yang dilakukan bertujuan untuk mendapat karakteristik dari kendaraan sehingga motor listrik yang baru dapat digunakan.

\section{METODE PELITIAN}

Metode penelitian dapat dilihat pada Gambar 1.

\section{URAIAN PENELITIAN}

\section{A. Motor Listrik}

Motor listrik merupakan sumber tenaga dari kendaraan listrik dan memiliki karakteristik berbeda dengan motor bensin. Berdasarkan karakterisitik pada gambar 1 dapat diketahui bahwa power atau tenaga dari motor listrik dibawah kecepatan dasar (base speed) akan terus bertambah secara linier sampai mencapai tenaga maksimum yang tepat berada saat berada pada kecepatan base. Dan dari kecepatan dasar sampai dengan kecepatan maksimum, tenaga yang dihasilkan motor listrik konstan sebesar tenaga maksimum yang dapat dihasilkan motor listrik. Sedangkan dari segi torsi yang dihasilkan oleh motor listrik berdasarkan karakteristik diatas dapat dijelaskan bahwa torsi akan tetap pada kecepatan dibawah kecepatan dasar, yaitu sebesar torsi maksimum yang dapat dihasilkan motor listrik. Lalu setelah melewati kecepatan dasar torsi dari motor listrik akan menurun secara hiperbolik.

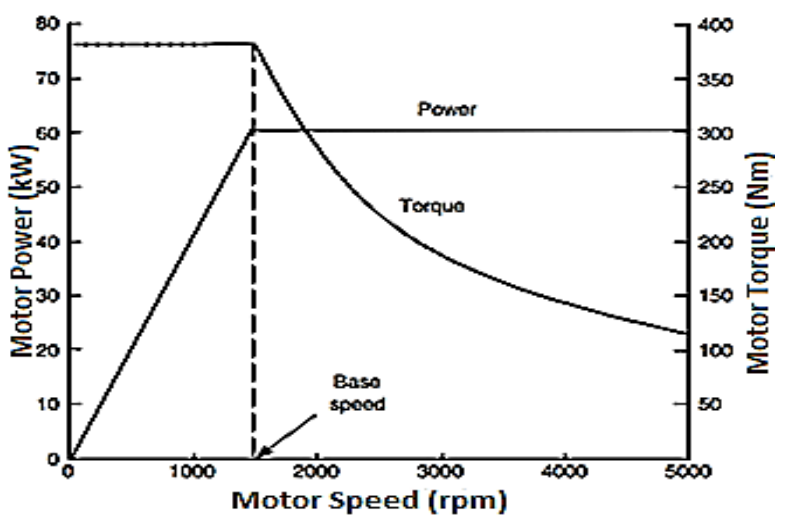

Gambar 2. Karakteristik Motor Listrik [5].

\section{B. Dinamika Kendaraan}

Gaya-gaya yang bekerja pada kendaraan berupa gaya hambat aerodinamis, gaya hambat rolling, serta gaya hambat gradien. Sesuai pada Gambar 3 untuk melawan gaya-gaya yang terjadi dibutuhkan gaya dorong atau Ft. Dimana gaya dorong kendaraan berasal dari tenaga mesin. Pada gambar $2 \mathrm{Ft}$ (gaya dorong) dibagi menjadi dua yaitu Ff (gaya dorong pada roda depan) dan Fr (gaya dorong pada roda belakang).

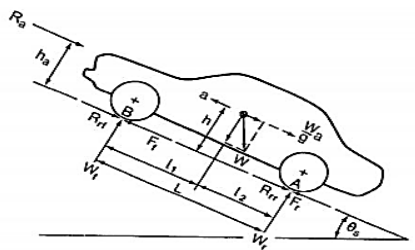

Gambar 3. Dinamika Kendaraan saat Menanjak [5].

Jenis gaya hambat yang pertama adalah gaya hambat yang terjadi karena hambatan udara atau disebut drag force. Drag force merupakan gaya yang menghambat gaya dorong kendaraan karena arah dari drag force berlawanan dengan arah laju kendaraan. Terdapat beberapa jenis dari gaya hambat angin (drag force) yaitu hambatan bentuk, hambatan pusaran / turbulensi, hambatan tonjolan dan hambatan aliran dalam. Dengan demikian, besarnya gaya hambat angin dapat dihitung dengan persamaan berikut,

$$
R_{a}=\frac{1}{2} \times \rho \times C d \times A f \times V a^{2}
$$

$R_{a}=$ hambatan aerodinamika $(\mathrm{N})$

$\rho \quad=$ massa jenis udara $\left(\mathrm{kg} / \mathrm{m}^{3}\right)$

$C d=$ koefisien drag

Af $=$ Luas frontal kendaraan $\left(\mathrm{m}^{2}\right)$

$V a=$ kecepatan relatif angin terhadap kendaraan $(\mathrm{m} / \mathrm{s})$

Gaya yang kedua adalah rolling resistant, yaitu gaya hambat akibat gesekan ban dengan jalan. Untuk mencari besarnya gaya hambat rolling, pertama kita harus menentukan besarnya koefisien hambatan rolling $(f r)$ terlebih dahulu. Besarnya $f r$ dapat dicari menggunakan persamaan hasil eksperimen J.J Taborek seperti (2), [6]

$$
f r=f o+f s\left(\frac{V}{100}\right)^{2,5}
$$

$\mathrm{Fr} \quad=$ koefisien hambat rolling

fo dan $f_{s}=$ koefisien yang nilainya tergantung pada tekanan ban

$V \quad=$ kecepatan kendaraan $(\mathrm{km} / \mathrm{h})$

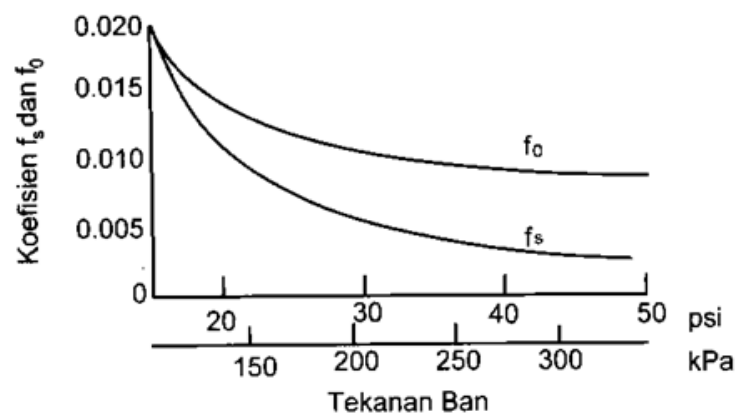

Gambar 4. Grafik Tekanan Ban terhadap Koefisien Hambat Rolling [5]. 
Setelah mendapatkan koefisien hambat rolling (fr), maka besarnya gaya hambat rolling dapat dicari yaitu,

$$
R r=f r \times W
$$

dimana,

$R r \quad$ = gaya hambat rolling $(\mathrm{N})$

$f r \quad=$ koefisien hambat rolling

$W=$ berat kendaraan $(\mathrm{N})$

Gaya hambat yang terakhir adalah gaya hambat yang terjadi karena adanya sudut tanjakan pada jalan. Dengan adanya gaya hambatan tanjakan maka beban kendaraan akan bertambah akibat pengaruh gaya gravitasi bumi. Besar gaya hambat akibat sudut tanjak dapat dihitung dengan rumus berikut,

$$
R g=W \sin \theta
$$

dimana,

$R g=$ gaya hambat tanjakan $(\mathrm{N})$

$W=$ berat kendaraan $(\mathrm{N})$

$\theta=$ sudut tanjakan

Besarnya gaya rolling resistance juga akan terpengaruhi oleh besarnya sudut tanjakan. Hal ini terjadi karena perbedaan gaya normal pada kendaraan yang besarnya lebih kecil dibandingkan saat jalan mendatar. Besarnya gaya normal kendaraan sama dengan berat kendaraan dikalikan cos sudut tanjakan. Sehingga gaya hambat total kendaraan saat kondisi jalan menanjak berubah menjadi,

$$
\begin{gathered}
F r=R a+R r \cos \theta+R g \\
F r=\left(\frac{1}{2} \times \rho \times C d \times A f \times V a^{2}\right)+(f r \times W \cos \theta)+W \sin \theta
\end{gathered}
$$

\section{Kebutuhan Tenaga dan Torsi Motor Listrik}

Dalam menentukan kebutuhan tenaga atau daya dari motor yang digunakan untuk kendaraan ini maka terlebih dahulu harus ditentukan besar sudut tanjakan maksimum dan kecepatan yang diinginkan saat kendaraan melalui jalan dengan sudut tanjakan maksimum, sehingga didapat gaya hambat kendaraan sesuai dengan (6), Setelah mengetahui gaya hambat pada kendaraan maka selanjutnya adalah menghitung besar torsi yang dibutuhkan oleh kendaraan berdasarkan variasi kecepatan dan sudut tanjakan maksimum kendaraan dengan rumus sebagai berikut,

$$
T p=F r \times R
$$

dimana

$R \quad$ = jari-jari roda penggerak pada kendaraan.

Setelah mengetahui torsi yang dibutuhkan kendaraan maka selanjutnya adalah mencari besar daya yang dibutuhkan kendaraan berdasarkan kecepatan yang diinginkan saat melalui jalan dengan sudut tanjakan maksimum, seperti pada persamaan dibawah ini

$$
P=F r \times V k
$$

Jadi daya untuk kendaraan $(P)$ dan torsi pada roda penggerak $(T p)$ adalah tenaga dan torsi yang berasal dari motor lalu ditransmisikan oleh drive train, maka untuk menentukan besarnya tenaga $(\mathrm{Pm})$ dan torsi $(\mathrm{Tm})$ dari motor listrik yang dibutuhkan dapat dihitung apabila diketahui efisiensi drive train adalah $(E d t)$ maka,

$$
P m=\frac{P}{E d t}
$$

\section{Sistem Transmisi Kendaraan}

Sistem transmisi adalah suatu sistem yang berfungsi untuk mengkonversikan torsi dan kecepatan dari mesin menjadi torsi dan kecepatan yang berbeda-beda dan selanjutnya diteruskan ke penggerak akhir. Dalam suatu kendaraan sistem transmisi adalah bagian dari sistem pemindah tenaga. Dengan adanya sistem transmisi maka putaran mesin dengan putaran poros yang dihubungkan dengan penggerak akhir dapat dikontrol. Fungsi dari kontrol sendiri supaya tenaga yang dihasilkan oleh mesin sesuai dengan kebutuhan kendaraan [7].

Maka yang pertama harus diperhitungkan adalah rasio transmisi pada tingkat gigi pertama. Hal ini karena pada tingkat pertama dibutuhkan torsi maksimum agar kendaraan bergerak, serta dengan diperhitungkannya torsi maksimum dapat diketahui seberapa besar sudut tanjakan jalan yang dapat dicapai dengan menggunakan rasio transmisi pertama. Dibawah ini merupakan rumus untuk menentukan besar rasio transmisi pertama,

$$
i_{1}=\frac{F t \times r}{T_{m} \times i_{d} \times \eta_{t}}=\frac{\left(W \sin \Theta_{\max }+f_{r} \cdot W \cos \theta+R a\right) r}{T_{m} \times i_{d} \times \eta_{t}}
$$

dimana,

$$
\begin{array}{ll}
F t & =\text { gaya torsi kendaraan } \\
W & =\text { berat kendaraan } \\
T_{m} & =\text { torsi mesin } \\
\eta_{t} & =\text { efisiensi dari transmisi } \\
r & =\text { jari-jari roda } \\
I_{d} & =\text { perbandingan gigi diferential. }
\end{array}
$$

Setelah menentukan rasio transmisi tingkat pertama, selanjutnya menentukan besar dari rasio transmisi terakhir pada kendaraan berdasarkan kecepatan maksimum yang ditentukan. Berdasarkan hal tersebut perumusan rasio transmisi pada tingkat gigi akhir adalah seperti dibawah ini,

$$
I_{m}=\frac{F t \times r}{T m \times i_{d} \times \eta_{t}}=\frac{\left(f_{r} \cdot W+\frac{1}{2} \rho \cdot C_{d} A_{f \cdot V_{m}}\right) r}{T m \times i_{d} \times \eta_{t}}
$$

\section{E. Traksi dan Power Kendaraan}

Gaya dorong atau gaya traksi yang terjadi pada roda $(F t)$ dengan efisiensi transmisi ( $E d t)$ dapat dihitung dengan perumusan seperti dibawah ini,

$$
F t=\frac{I t \times I g \times T m}{R} E d t
$$

dimana,

It $=$ rasio transmisi

Ig = rasio gardan

$\mathrm{Tm}=$ torsi motor

$E d t=$ efisiensi drive train

Dalam menentukan karakteristik traksi kendaraan terlebih dahulu harus mencari kecepatan dasar untuk setiap tingkat transmisi (Vbn) dan gaya traksi untuk setiap tingkat transmisi (Ftn). Setelah mengetahui data-data diatas maka karakteristik traksi kendaraan dapat diketahui dan fungsi dari karakteristik traksi kendaraan adalah sebagai penggambaran besar gaya traksi yang dapat dihasilkan kendaraan pada setiap kecepatan, serta dapat mengetahui kecepatan, percepatan dan sudut tanjakan maksimum yang dapat dilalui kendaraan [8].

Untuk mengetahui besar dari kecepatan dasar $\left(V_{b n}\right)$ dan kecepatan maksimum $\left(V_{\text {nmak }}\right)$ kendaraan dengan tingkat transmisi $\mathrm{n}\left(V_{b n}\right)$ dapat dihitung dengan perumusan sebagai berikut,

$$
V_{b n}=\frac{\pi \times R \times N b}{30 \times I t n \times I g}
$$




$$
V_{n \max }=\frac{\pi \times R \times N m_{\max }}{30 \times I t n \times I g}
$$

dimana,

$\mathrm{Nb} \quad=$ putaran dasar motor listrik

$N m_{\max }=$ putaran maksimum motor listrik

$I_{t n} \quad=$ rasio transmisi ke "n".

Setelah mengetahui kecepatan dasar dan kecepatan maksimum pada tiap tingkat transmisi selanjutnya adalah menetukan gaya traksi maksimum dan minimum yang dapat dihasilkan pada tingkat transmisi. Gaya traksi maksimum yang dihasilkan motor terjadi ketika putaran 0 sampai pada putaran dasar, hal ini karena torsi yang terjadi adalah konstan sesuai dengan grafik sedangkan setelah kecepatan konstan maka torsi motor akan turun begitu juga dengan gaya traksi kendaraan. Konsep ini sangat sesuai dengan kebutuhan kendaraan, dimana kebutuhan traksi sangat diperlukan saat kecepatan awal, sedangkan untuk kecepatan yang terus bertambah kebutuhan traksi kendaraan akan berkurang. Dibawah ini merupakan perumusan untuk mencari besar gaya traksi maksimum dan minimum yang dapat dihasilkan pada tingkat transmisi " $n$ ",

$$
\begin{gathered}
F t_{\text {max }}=\frac{I t n \times I g \times T m_{\text {max }}}{R} E d t \\
F t_{\text {min }}=\frac{I t n \times I g \times T m_{\text {min }}}{R} E d t
\end{gathered}
$$

dimana,

$T_{\max }=$ torsi motor listrik maksimum

$T_{\text {min }}=$ torsi motor listrik minimum

Karakteristik power suatu kendaraan menunjukkan seberapa besar power yang dapat diberikan sistem transmisi untuk memenuhi kebutuhan power yang dibutuhkan akibat adanya gaya hambat. Karakteristik power yang dihasilkan oleh kendaraan listrik adalah terdiri dari grafik power atau daya dari masing-masing tingkat transmisi yang nantinya akan diplotkan dengan grafik daya yang dibutuhkan akibat terjadinya gaya hambat. Untuk menghitung power yang didapat dari masingmasing tingkat transmisi adalah dengan rumus sebagai berikut,

$$
P t=F t \times V
$$

dimana

$P t=$ power yang diberikan oleh trasmisi $(\mathrm{KW})$

$F t=$ gaya dorong tiap transmisi $(\mathrm{N})$

$V=$ kecepatan kendaraan $(\mathrm{m} / \mathrm{s})$.

Sedangkan untuk menentukan besarnya power yang dibutuhkan oleh adanya gaya hambat dapat dilihat berdasarkan rumus,

$$
\operatorname{Pr}=F r \times V
$$

dimana

$\operatorname{Pr}=$ power yang diakibatkan oleh gaya hambat $(\mathrm{KW})$

$F r=$ gaya hambat total $(\mathrm{N})$

$V=$ kecepatan kendaraan $(\mathrm{m} / \mathrm{s})$.

\section{HASIL DAN ANALISIS}

\section{A. Informasi Umum}

Informasi spesifikasi standard mobil listrik Ezzy ITS II (Tabel 1) memiliki karakteristik traksi yang disajikan pada Gambar 5.
Tabel 1.

Spesifikasi Ezzy ITS II

\begin{tabular}{ll}
\hline \hline Type & Sporty Hatchback City Car \\
\hline Capacity & 4 (Termasuk Driver) orang \\
Chassis & Monocoque \\
Penggerak & Front Wheel with BLDC Motor \\
Power & $60 \mathrm{Kw}$ \\
Maximum Speed & $+180 \mathrm{~km} / \mathrm{jam}$ \\
Torque & $200 \mathrm{~N} . \mathrm{m}$ \\
Battery & Battery LiPoFe4; 20 Kwh \\
Energy Consumption & $8 \mathrm{~km} / \mathrm{kwh}$ \\
Control System & BMS dan Android \\
Charging & $10 \mathrm{jam}$ (Slow Charging) \\
Dimention (PxLxT) & $3500 \mathrm{~mm}$ x 1500 mm x $1400 \mathrm{~mm}$ \\
Wheelbase & $2334 \mathrm{~mm}$ \\
Track Width & $1183 \mathrm{~mm}$ \\
Ground clearance & $181 \mathrm{~mm}$ \\
Weight & $1500 \mathrm{~kg}$ \\
4 roda tunggal & Radial (P 205/45 R17) \\
Drag coefficient Cd claimed: & \\
Drag coefficient Cd estimated by a-c: & \\
Frontal area A claimed: & 0,4 \\
Frontal area A estimated by a-c: & $1.79 \mathrm{~m} 2$ \\
Transmission & manual syncromesh \\
Gear ratio & 1 \\
& 2 \\
\hline \hline
\end{tabular}

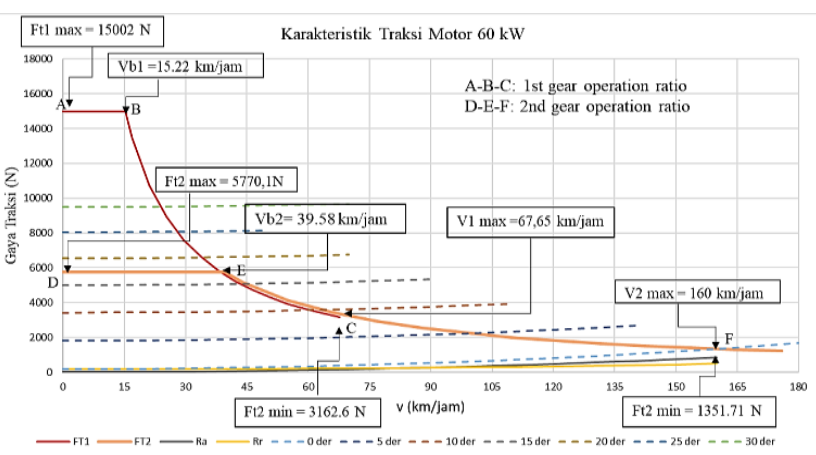

Gambar 5. Karakteristik Traksi Ezzy ITS II 60 kW.

Gambar 5 merupakan grafik karakteristik traksi Mobil Listrik Ezzy II ITS menggunakan motor 60kW dengan 2 tingkat transmisi. Terlihat berdasarkan grafik bahwa karakteristik pada transmisi pertama dengan rasio transmisi 3,25 mobil dapat melewati tanjakan 30 derajat dengan kecepatan $24 \mathrm{~km} / \mathrm{jam}$ dan kecepatan maksimal sebesar $67,65 \mathrm{~km} / \mathrm{jam}$ pada jalan datar. Pada transmisi kedua dengan rasio transmisi 1,25 mobil dapat melalui tanjakan 15 derajat dengan kecepatan $45 \mathrm{~km} / \mathrm{jam}$ dan pada jalan datar dengan kecepatan maksimum 160 km/jam.

\section{B. Redesign Sistem Tenaga}

Suatu kendaraan untuk dapat berjalan memerlukan sumber tenaga penggerak, dimana sumber tenaga tersebut harus dapat melawan gaya hambat yang terjadi pada kendaraan. Setelah didapat besar dari gaya hambat kendaraan, baik itu gaya hambat angin, gaya hambat rolling atau gaya hambat karena tanjakan. Jadi langkah selanjutnya adalah menentukan besar power atau daya dari sumber penggerak yang diperlukan. Berdasarkan (8) dapat diketahui besar daya yang diperlukan oleh kendaraan. Berikut ini merupakan grafik dari perhitungan kebutuhan daya kendaraan untuk dapat berjalan melewati gaya hambat yang terjadi, 


\section{Kebutuhan Daya pada Roda}

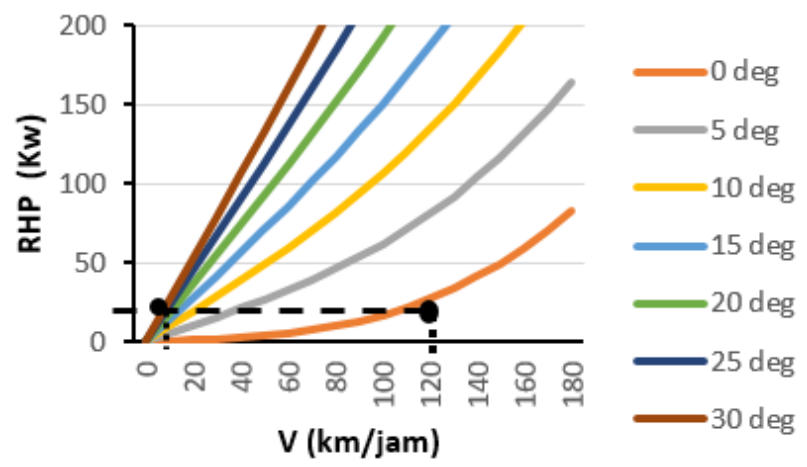

Gambar 6. Daya Hambatan Kendaraan di Roda.

Berdasarkan grafik pada Gambar 6, dapat dijelaskan bahwa dengan power atau daya sebesar $25 \mathrm{kw}$, kendaraan dapat melaju pada tanjakan 30 derajat dengan kecepatan kurang lebih 10 $\mathrm{km} / \mathrm{jam}$. Jadi dengan power sebesar $25 \mathrm{kw}$ kendaraan dapat mencapai kecepatan kurang lebih $120 \mathrm{~km} / \mathrm{jam}$ pada jalan mendatar. Akan tetapi perlu diingat daya diatas merupakan daya pada roda penggerak, bukan daya yang dihasilkan pada sumber tenaga atau motor listrik. Jadi dalam menentukan spesifikasi motor yang digunakan pada Mobil Listrik Ezzy II ITS harus menggunakan power yang melebihi dari grafik diatas, karena power yang dihasilkan oleh sumber tenaga atau motor merupakan power pada grafik diatas dibagi dengan efisiensi kendaraan seperti pada (9).

1) Motor Listrik dan Baterai

Perhitungan Daya Motor Listrik

Pada perhitungan sebelumnya telah didapat besar daya dari gaya hambat kendaraan. Jadi langkah selanjutnya adalah menentukan besar power atau daya dari sumber penggerak yang diperlukan untuk dapat melawan gaya hambat tersebut. Berdasarkan (9) dimana efisiensi dari drive train sebesar 0,85 dapat diketahui besar daya motor listrik yang diperlukan oleh kendaraan.

Berdasarkan grafik pada Gambar 7, dapat dijelaskan bahwa dengan power atau daya sebesar $30 \mathrm{kw}$, kendaraan dapat melaju pada tanjakan 30 derajat dengan kecepatan kurang lebih 10 $\mathrm{km} / \mathrm{jam}$. Serta dengan power sebesar $30 \mathrm{kw}$ kendaraan dapat mencapai kecepatan kurang lebih $120 \mathrm{~km} / \mathrm{jam}$ pada jalan mendatar. Sehingga daya motor listrik $30 \mathrm{kw}$ dapat digunakan pada rancangan ini.

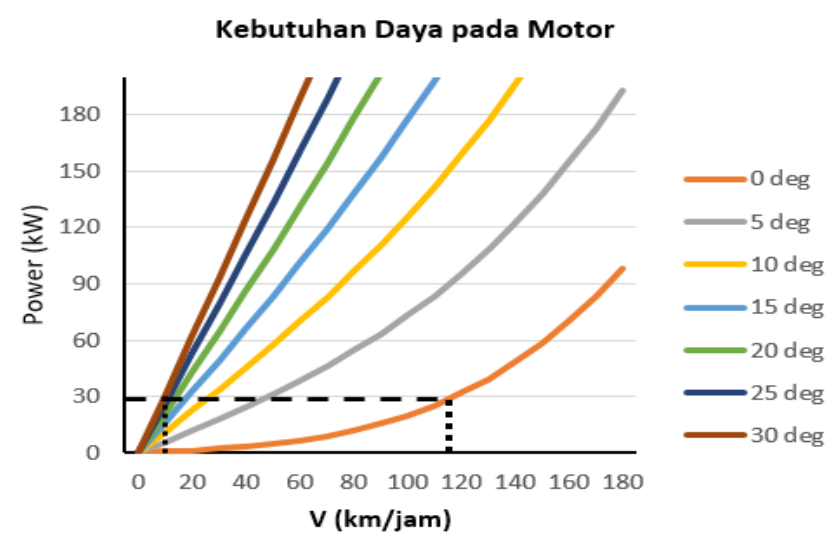

Gambar 7. Kebutuhan Daya di Motor Listrik.
Pemilihan Motor Listrik

Setelah mengetahui gaya hambat yang terjadi serta kebutuhan daya untuk jalan kendaraan, penulis melakukan survey mengenai motor listrik yang sesuai untuk Mobil Listrik Ezzy II ITS. Berdasarkan beberapa jenis motor yang tersedia maka penulis memilih menggunakan motor Yasa P400 Series

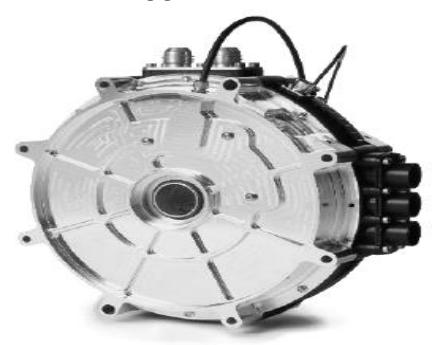

\begin{tabular}{|c|c|}
\hline Peak torque@450 ARMs ${ }^{2}$ & $370 \mathrm{Nm}$ \\
\hline Continuous Torque ${ }^{2}$ & Up to $200 \mathrm{Nm}$ \\
\hline Peak Power@700 Voc ${ }^{2}$ & $160 \mathrm{~kW}$ \\
\hline Continuous Power ${ }^{2}$ & $20 \mathrm{~kW}$ to $100 \mathrm{~kW}$ \\
\hline Speed & $0-8000 \mathrm{rpm}$ \\
\hline Peak Efficiency s & $96 \%$ \\
\hline Dry Mass ^ & from $24 \mathrm{~kg}$ \\
\hline
\end{tabular}

Gambar 8. Spesifikasi Motor YASA P400 Series [9].

Gambar 8 merupakan penampakan dari motor serta spesifikasi dari motor Yasa P400 Series. Berdasarkan spesifikasi diketahui motor dapat menghasilkan power sebesar 20-100 kw. Jadi setelah penulis mendapatkan spesifikasi motor yang sesuai maka penulis mencari grafik dari power beserta torsi yang dihasilkan oleh motor Yasa P400 Series. Untuk grafik power dan torsi dari motor Yasa $\mathrm{P} 400$ Series dapat dilihat pada Gambar 9,

\section{Power and Torque}

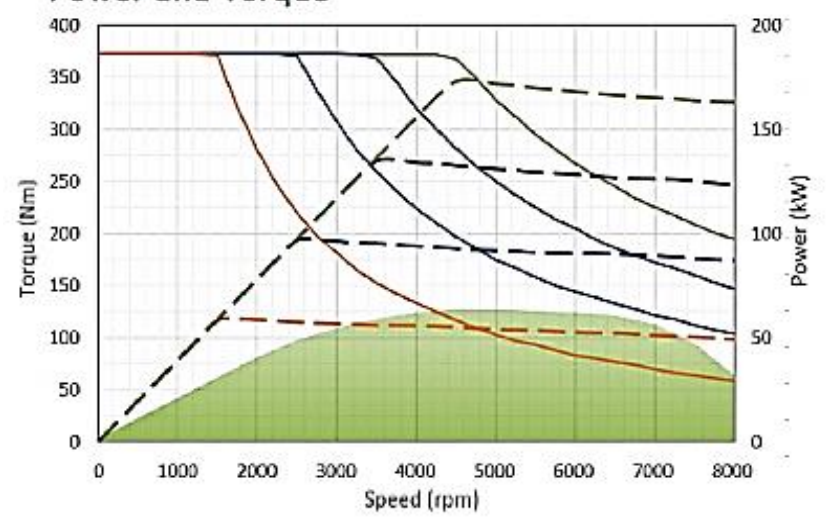

Gambar 9. Grafik Power dan Torsi Motor [7].

Terlihat dari Gambar 9 menunjukkan kemampuan dari motor listrik untuk menghasilkan power maupun torsi. Torsi maksimal yang dapat dihasilkan motor Yasa P400 Series adalah $370 \mathrm{Nm}$, sesuai dengan teori menyatakan bahwa torsi pada motor listrik adalah maksimum dari putaran awal sampai putaran base lalu akan turun secara hyperbolic sampai putaran maksimal. Torsi yang dihasilkan motor Yasa P400 series adalah bevariasi tergantung power dari motor, semakin lama putaran motor untuk mencapai torsi maksimum maka semakin besar pula power yang digunakan oleh motor. Dan untuk karakteristik power pada motor Yasa P400 series adalah terus naik seiring 
bertambahnya kecepatan dari motor dan akan konstan apabila mencapai kecepatan base. Semakin besar power dari motor Yasa P400 series maka kecepatan base juga semakin besar, sehingga torsi yang dihasilkan juga semakin besar. Penulis menggunakan motor Yasa P400 series dengan power sebesar $30 \mathrm{kw}$.

\section{Redesign Transmisi}

Pada perhitungan rasio transmisi penulis menghitung terlebih dahulu pada tingkat rasio pertama. Sehingga berdasarkan (10) dapat diketahui hasilnya sebagai berikut,

$i_{1}=\frac{F t \times r}{T_{m} \times i_{d} \times \eta_{t}}=\frac{\left(W \sin \theta_{\max }+f_{r} . W \cos \theta+R a\right) r}{T_{m} \times i_{d} \times \eta_{t}}$

$i_{1}=\frac{(10906) 0,31}{370 \times 4,25 \times 0,91}$

$i_{1}=2,362$

Selanjutnya penulis menghitung rasio transmisi untuk kecepatan akhir. Rasio transmisi akhir merupakan tingkat transmisi yang digunakan kendaraan untuk dapat menghasilkan kecepatan yang diinginkan, disini penulis menetapkan sampai dengan kecepatan 100 km/jam karena 100 km/jam merupakan kecepatan maksimal yang diijinkan pada saat berkendara. Berdasarkan (11) menjelaskan cara untuk menghitung rasio transmisi akhir,

$i_{2}=\frac{F t \times r}{T m \times I d \times \eta_{t}}=\frac{\left(f_{r} \cdot W+\frac{1}{2} \rho . C_{d} A_{f . V_{m}}\right) r}{T m \times i d \times \eta_{t}}$

$i_{2}=\frac{(1665,5) 0,31}{370 \times 4,25 \times 0,91}$

$i_{2}=0,36$

Dalam menentukan karakteristik traksi suatu kendaraan, terlebih dahulu penulis menghitung besar dari kecepatan serta gaya dorong yang dapat dihasilkan dari rasio setiap tingkat transmisi yang ada. Untuk kecepatan yang dapat dihasilkan dari rasio transmisi dapat dihitung berdasarkan (13) dan (14). Maka hasil dari perhitungan kecepatan dasar dan maksimum rasio transmisi pertama adalah

$V_{1 b}=\frac{\pi \times R \times N b}{30 \times I t n \times I g} \times \frac{3600 s}{1000 m}\left(\frac{\mathrm{km}}{j a m}\right)$

$V_{1 b}=\frac{3,14 \times 0,31 \mathrm{~m} \times 850 \mathrm{rpm}}{30 \times 2,362 \times 4,25} \times \frac{3600 \mathrm{~s}}{1000 \mathrm{~m}}\left(\frac{\mathrm{km}}{\mathrm{jam}}\right)$

$V_{1 b}=9,89 \frac{\mathrm{km}}{j a m}$

$V_{1 \max }=\frac{\pi \times R \times N m_{\max }}{30 \times I t n \times I g} \times \frac{3600 \mathrm{~s}}{1000 \mathrm{~m}}\left(\frac{\mathrm{km}}{\mathrm{jam}}\right)$

$V_{1 \max }=\frac{3,14 \times 0,31 \mathrm{~m} \times 8000 \mathrm{rpm}}{30 \times 2,362 \times 4,25} \times \frac{3600 \mathrm{~s}}{1000 \mathrm{~m}}\left(\frac{\mathrm{km}}{\mathrm{jam}}\right)$

$V_{1 \max }=93,09 \frac{\mathrm{km}}{\mathrm{jam}}$

Lalu untuk kecepatan dasar dan maksimum rasio transmisi akhir adalah

$V_{2 b}=\frac{\pi \times R \times N b}{30 \times I t n \times I g} \times \frac{3600 s}{1000 m}\left(\frac{\mathrm{km}}{j a m}\right)$

$$
\begin{gathered}
V_{2 b}=\frac{3,14 \times 0,31 \mathrm{~m} \times 850 \mathrm{rpm}}{30 \times 0,36 \times 4,25} \times \frac{3600 \mathrm{~s}}{1000 \mathrm{~m}}\left(\frac{\mathrm{km}}{\mathrm{jam}}\right) \\
V_{2 b}=64,89 \frac{\mathrm{km}}{\mathrm{jam}} \\
V_{2 \max }=\frac{\pi \times R \times \mathrm{Nm} \text { max }}{30 \times \mathrm{Itn} \times \mathrm{Ig}} \times \frac{3600 \mathrm{~s}}{1000 \mathrm{~m}}\left(\frac{\mathrm{km}}{\mathrm{jam}}\right) \\
V_{2 \max }=\frac{3,14 \times 0,31 \mathrm{~m} \times 8000 \mathrm{rpm}}{30 \times 0.36 \times 4,25} \times \frac{3600 \mathrm{~s}}{1000 \mathrm{~m}}\left(\frac{\mathrm{km}}{\mathrm{jam}}\right) \\
V_{2 \max }=610,76 \frac{\mathrm{km}}{\mathrm{jam}}
\end{gathered}
$$

Berdasarkan perhitungan diatas dapat diketahui bahwa kecepatan dasar $\left(V_{l b}\right)$ dari rasio transmisi pertama adalah 9,89 $\mathrm{km} / \mathrm{jam}$ dan kecepatan maksimum $\left(V_{l_{\max }}\right)$ adalah 93,09 km/jam, sedangkan untuk kecepatan dasar $\left(V_{2 b}\right)$ dari rasio transmisi akhir adalah 64,89 km/jam dan kecepatan maksimum $\left(V_{2 m a x}\right)$ adalah $610,76 \mathrm{~km} / \mathrm{jam}$. Dalam menghitung kecepatan tersebut penulis menggunakan spesifikasi motor dengan range putaran 0-8000 rpm.

Setelah mendapat kecepatan yang dihasilkan rasio transmisi, selanjutnya penulis menghitung gaya dorong minimal serta maksimal yang dihasilkan rasio transmisi. Berdasarkan (15) dan (16) maka besar gaya dorong yang dapat dihasilkan oleh rasio transmisi pertama adalah sebagai berikut,

$$
\begin{gathered}
F t_{1 \text { max }}=\frac{I t n \times I g \times T m_{\text {max }}}{R} E d t \\
F t_{1 \text { max }}=\frac{2,362 \times 4,25 \times 370 \mathrm{Nm}}{0,31 \mathrm{~m}} 0,91 \\
F t_{1 \text { max }}=10903 \mathrm{~N} \\
F t_{1 \text { min }}=\frac{I t n \times I g \times T m_{\text {min }}}{R} E d t \\
F t_{1 \text { min }}=\frac{2,362 \times 4,25 \times 40 \mathrm{Nm}}{0,31 \mathrm{~m}} 0,91 \\
F t_{1 \text { min }}=1178,7 \mathrm{~N}
\end{gathered}
$$

Dan untuk gaya dorong yang dihasilkan oleh rasio transmisi akhir berdasarkan perhitungan adalah sebagai berikut,

$$
\begin{gathered}
F t_{2 \max }=\frac{I t n \times I g \times \mathrm{Tm}_{\max }}{R} E d t \\
F t_{2 \max }=\frac{0,36 \times 4,25 \times 370 \mathrm{Nm}}{0,31 \mathrm{~m}} 0,91 \\
F t_{2 \max }=1661,8 \mathrm{~N} \\
F t_{2 \min }=\frac{I t n \times I g \times \mathrm{Tm}_{\min }}{R} E d t \\
F t_{2 \min }=\frac{0,36 \times 4,25 \times 40 \mathrm{Nm}}{0,31 \mathrm{~m}} 0,91 \\
F t_{2 \min }=179,65 \mathrm{~N}
\end{gathered}
$$

Berdasarkan perhitungan diatas maka dapat diketahui pada rasio transmisi pertama besar dari gaya dorong maksimal adalah $10903 \mathrm{~N}$ dan gaya dorong minimal adalah 1178,7 $\mathrm{N}$, 
sedangkan pada rasio tranmisi akhir besar gaya dorong maksimal adalah 1661,8 $\mathrm{N}$ dan gaya dorong minimal adalah $179,65 \mathrm{~N}$. Terlihat berdasarkan perhitungan pada rasio transmisi pertama memiliki nilai gaya dorong yang lebih besar dari rasio transmisi terakhir, hal ini karena pada rasio transmisi pertama berfungsi untuk kendaraan pada konsisi jalan menanjak atau saat kendaraan sedang awal akan bergerak dimana membutuhkan torsi yang tinggi, sedangkan pada rasio akhir berfungsi saat kendaraan dipacu pada jalan yang datar untuk mendapat kecepatan maksimum. Torsi maksimal dan torsi minimal dari motor listrik didapat sesuai dengan range spesifikasi motor 30kW YASA P400 yang digunakan yaitu 370 $\mathrm{Nm}$ pada torsi maksimal dan $40 \mathrm{Nm}$ pada torsi minimal.

\section{Hasil Redesign Daya Motor dan Transmisi}

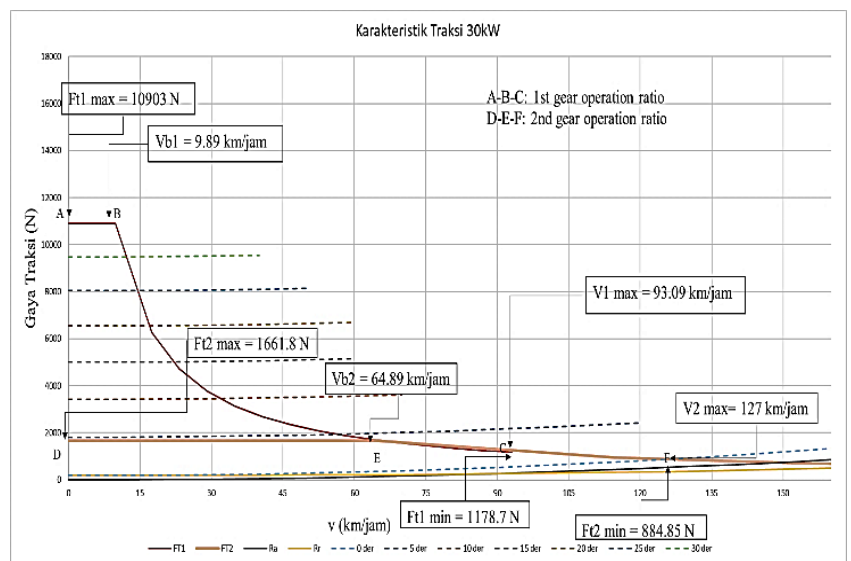

Gambar 10. Karakteristik Traksi Hasil Redesign.

Gambar 10 merupakan grafik karakteristik traksi Mobil Listrik Ezzy II ITS menggunakan motor 30kW dengan 2 tingkat transmisi. Terlihat berdasarkan grafik bahwa karakteristik pada transmisi pertama dengan rasio transmisi 2,362 mobil dapat melewati tanjakan 30 derajat dengan kecepatan $12 \mathrm{~km} / \mathrm{jam}$ dan kecepatan maksimal sebesar 93,09 km/jam pada jalan datar. Pada transmisi kedua dengan rasio transmisi 0,36 mobil dapat melalui jalan datar dengan kecepatan hingga $127 \mathrm{~km} / \mathrm{jam}$. Grafik tersebut sesuai dengan teori yang ada pada karakteristik mobil listrik yaitu gaya traksi akan konstan hingga kecepatan dasar dan setelah melewati kecepatan dasar gaya traksi menurun secara hiperbolik. Sehingga pada awal tarikan, gaya traksi yang dihasilkan sudah besar dan semakin turun hingga kecepatan maksimal yang dapat dicapai.

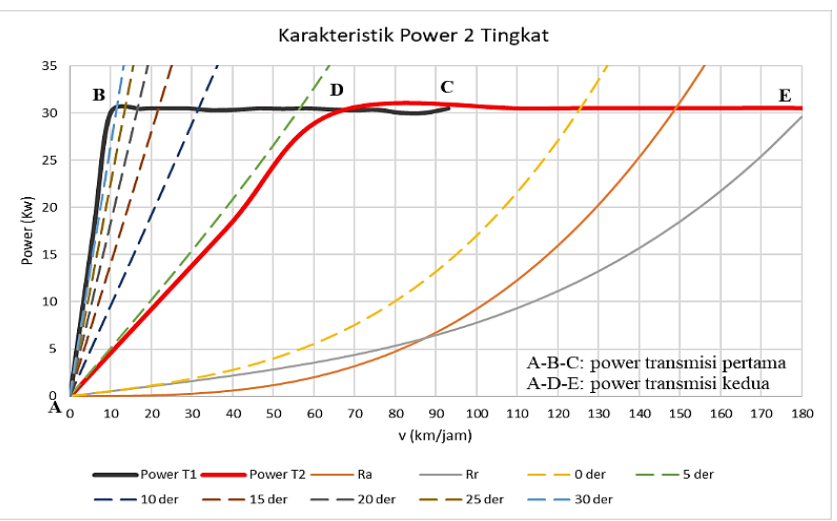

Gambar 11. Karakteristik Power Hasil Redesign.
Gambar 11 menunjukan karakteristik power pada Mobil Listrik Ezzy II ITS hasil redesign dengan 2 tingkat transmisi, dimana pada grafik tersebut terlihat power yang dibutuhkan oleh kendaraan akibat adanya gaya hambat dibandingkan dengan power yang dapat dihasilkan oleh motor sebagai sumber tenaga dari kendaraan. Terlihat pada grafik untuk tranmisi tingkat pertama power maksimum dari motor digunakan seluruhnya pada sudut 30 derajat dan menghasilkan kecepatan maksimum sebesar $12 \mathrm{~km} / \mathrm{jam}$. Dengan power motor $30 \mathrm{kw}$ kecepatan maksimum yang dapat dihasilkan untuk melewati jalan datar adalah 93,09 km/jam, hal ini karena pada jalan datar power keseluruhan dari motor sama dengan power yang dibutuhkan untuk melawan gaya hambat. Sedangkan pada transmisi tingkat kedua power yang dihasilkan oleh motor hanya dapat melalui medan jalan datar, kecepatan maksimum yang dihasilkan pada kondisi tersebut adalah $127 \mathrm{~km} / \mathrm{jam}$ dengan kosumsi power sebesar $30 \mathrm{kw}$.

Jadi berdasarkan perbandingan antara Mobil Listrik Ezzy II ITS yang sudah ada dan rancangan baru dengan motor $30 \mathrm{~kW}$ didapat untuk Mobil Listrik Ezzy II ITS dengan motor $60 \mathrm{~kW}$ memiliki traksi yang lebih besar dan dapat melewati tanjakan 30 derajat pada transmisi pertama sebesar $24 \mathrm{~km} / \mathrm{jam}$. Pada transmisi kedua dapat melewati tanjakan 15 derajat dengan kecepatan $45 \mathrm{~km} / \mathrm{jam}$ dan pada jalan datar dengan kecepatan maksimum $160 \mathrm{~km} / \mathrm{jam}$. Namun dengan daya motor lebih besar akan menyebabkan konsumsi daya lebih besar. Sedangkan pada rancangan baru dengan rasio transmisi yang berbeda dan motor $30 \mathrm{~kW}$ mampu melewati tanjakan 30 derajat dengan kecepatan $12 \mathrm{~km} / \mathrm{jam}$ dan kecepatan maksimal sebesar $93.09 \mathrm{~km} / \mathrm{jam}$ pada jalan datar. Pada transmisi kedua hanya mampu digunakan pada jalan datar dengan kecepatan maksimal 127 km/jam. Namun pada rancangan baru sudah dapat memenuhi kebutuhan yang diinginkan yaitu dapat melewati tanjakan 30 derajat dengan kecepatan $10 \mathrm{~km} / \mathrm{jam}$ dan pada jalan datar dengan kecepatan $100 \mathrm{~km} / \mathrm{jam}$. Dan dengan daya motor lebih kecil pada rancangan baru maka konsumsi daya juga akan lebih kecil.

\section{KESIMPULAN/RINGKASAN}

Kesimpulan berdasarkan data dan analisa yang telah dilakukan, diperoleh beberapa kesimpulan penelitian sebagai berikut. Pada kondisi standar, Mobil Listrik Ezzy ITS II mampu beroperasi mencapai kecepatan maksimum sebesar 160 $\mathrm{km} / \mathrm{jam}$ pada tingkat gigi terakhir dan dapat melewati tanjakan 30 derajat dengan kecepatan $24 \mathrm{~km} / \mathrm{jam}$ pada tingkat gigi pertama. Setelah melakukan redesign, hasil redesign Mobil Listrik Ezzy II ITS memiliki dua tingkatan, tingkat pertama memiliki rasio 2.362 dan 0.36 pada tingkat kedua. Berdasarkan rasio transmisi yang digunakan pada tingkat pertama dengan gaya traksi maksimum sebesar $10903 \mathrm{~N}$ kendaraan dapat melewati sudut tanjakan 30 derajat pada kecepatan $12 \mathrm{~km} / \mathrm{jam}$ dan dengan gaya traksi sebesar 1178,8 $\mathrm{N}$ kendaraan dapat melaju pada kecepatan 93,09 km/jam di jalan datar. Sedangkan untuk tingkat transmisi kedua dengan gaya traksi sebesar 1661,8 N kendaraan dapat melaju hingga kecepatan 127 $\mathrm{km} / \mathrm{jam}$ pada jalan datar. Pada kondisi standar Mobil Listrik Ezzy II ITS dengan daya motor $60 \mathrm{~kW}$ memiliki kecepatan lebih besar diberbagai medan jalannya dibandingkan pada hasil redesign dengan daya motor $30 \mathrm{~kW}$, namun konsumsi dayanya juga akan lebih besar sehingga jarak tempuh lebih singkat. 
Mobil Listrik Ezzy II ITS dengan daya motor $30 \mathrm{Kw}$ dapat dipilih karena sudah mampu memenuhi parameter yang diinginkan yaitu dapat melewati tanjakan 30 derajat dengan kecepatan $10 \mathrm{~km} / \mathrm{jam}$ dan pada jalan datar dengan kecepatan $100 \mathrm{~km} / \mathrm{jam}$. Saran penulis dalam proses melakukan karakteristik penggerak sebaiknya melalui uji dynotest kendaraan untuk mendapatkan hasil efisiensi drivetrain yang optimal. Perlunya analisa konsumsi energi dari rancangan system tenaga dan transmisi yang baru agar dapat membuktikan kemampuan untuk memperoleh jarak tempuh yang lebih panjang.

\section{DAFTAR PUSTAKA}

[1] B. MIGAS, "Konsumsi BBM Nasional," 2016. [Online]. Available: http://www.bphmigas.go.id/konsumsi-bbm-nasional.

[2] Republika, "Bahan Bakar Fosil Habis 35 Tahun Lagi,"
Republika.co.id, 2015. [Online]. Available: https://www.republika.co.id/berita/nasional/umum/16/02/16/o2ndw 3284-peneliti-sebut-energi-fosil-habis-2050.

[3] Dinas Perhubungan, "Dampak Emisi Kendaraan Bermotor," 2015. .

[4] Anonymous, "Keunggulan Mobil Listrik," 2017. [Online]. Available: https://finance.detik.com/energi/d-3618682/lebih-irit-pakai-mobillistrik-atau-bensin-ini-hasil-riset-esdm.

[5] S. . Nyoman, Teknologi Otomotif Hybrid. Surabaya: Guna Widya, 2015.

[6] J. J. Taborek, Mechanics of Vehicles. Ohio: Penton Publishing Co, 1957.

[7] Purboputro, M. A. Saputro, W. Setiadi, and M. Alfatih, "Uji Kemampuan Rancangan Sistem Kemudi, Transmisi, dan Pengereman pada Mobil Listrik Prototype Ababil," Jur. Tek. Mesin, vol. 1 , no. 1 , pp. 50-53.

[8] Prasetyo and W. Unggul, "Desain dan Analisa Sistem Tenaga dan Transmisi pada Mobil Angkutan Multiguna Pedesaan Bertenaga Listrik,”J. Jur. Tek. Mesin, vol. 6, no. 2, 2017.

[9] yasa.com, "YASA P400 Product Sheet." [Online]. Available: https://www.yasa.com/wpcontent/uploads/2018/01/YASA_P400_ Product_Sheet.pdf. 